\title{
GENETIC DIVERSITY AND STRUCTURE IN NATURAL POPULATIONS OF CAJUI FROM BRAZILIAN CERRADO
}

\author{
Maria Fernanda da Costa GOMES ${ }^{1}$ (D), Artemisa Nazaré Costa BORGES ${ }^{2}$ iD, \\ Giovana Sarah Sales BATISTA ${ }^{3}$ (D), Gizele de Andrade LUZ ${ }^{4}$ (D), Maria Edileide Alencar OLIVEIRA ${ }^{5}$ (i), \\ Ângela Celis de Almeida LOPES $^{6}$ (i) , Ademir Sérgio Ferreira de ARAÚJO ${ }^{7}$, \\ Regina Lucia Ferreira GOMES ${ }^{6}$ (D), Fábio Barros BRITTO ${ }^{8}$ (D), Paulo Sarmanho da Costa LIMA ${ }^{9}$ (D), \\ Sérgio Emílio dos Santos VALENTE ${ }^{8}$ iD
}

\footnotetext{
${ }^{1}$ Department of Biology, State University of Piauí, São Raimundo Nonato, Piauí, Brazil.

2 Department of Education, Federal Institute of Maranhão, Buriticupu, Maranhão, Brazil.

${ }^{3}$ Postgraduate Program in Genetics and Breeding, Federal University of Piauí, Teresina, Piauí, Brazil.

${ }_{4}^{4}$ Postgraduate Program in Biological Sciences, Federal University of Pernambuco, Recife, Pernambuco, Brazil.

${ }^{5}$ Department of Teacher Training, Instituto Federal do Piauí, Teresina, Piauí, Brazil.

${ }^{6}$ Department of Plant Science, Federal University of Piauí, Teresina, Piauí, Brazil.

7 Department of Agricultural and Soil Engineering, Federal University of Piauí, Teresina, Piauí, Brazil.

8 Department of Biology, Federal University of Piauí, Teresina, Piauí, Brazil.

${ }^{9}$ Embrapa Meio-Norte, Brazilian Agricultural Research Corporation, Teresina, Piauí, Brazil.
}

Corresponding author:

Sérgio Emílio dos Santos Valente

Email: svalente@ufpi.edu.br

How to cite: GOMES, M.F.C., et al. Genetic diversity and structure in natural populations of Cajui from Brazilian cerrado. Bioscience Journal. 2021, 37, e37080. https://doi.org/10.14393/BJ-v37n0a2021-53974

\begin{abstract}
Cajui (Anacardium spp.) is a native fruit tree (small cashew) of the Brazilian Cerrado and possesses the potential for commercialization. However, cajui exploitation occurs exclusively through extractivism in the absence of conservation strategies. The lack of conservation strategies may lead to a decrease in genetic diversity of Anacardium. In this work, the genetic diversity and population structure of three natural populations in Sete Cidades National Park (PNSC; PI, Brazil) were assessed using ISSR analysis of 56 cajui accessions and two $A$. occidentale accessions (outgroup) from Pacajus (CE, Brazil). A total of 112 markers were obtained, 93 (83.04\%) of which were polymorphic. The diversity indices of these populations indicated moderate levels of genetic diversity. According to AMOVA, $96.17 \%$ of the genetic variability lay within populations, with low genetic differentiation among populations $\left(\Phi_{\mathrm{ST}}=0.03828\right)$. Furthermore, STRUCTURE analysis indicated the existence of four connected genetic groups. The findings show that the individuals from the three collection sites did not represent different subpopulations, likely due to the high gene flow $(\mathrm{Nm}=6.7)$ favored by the floral biology of Anacardium, pollinators and small-animal seed dispersers. This research identifies genetically divergent individuals (C-03, C-05, C-22, C-26, C-34 and C-39), which should be considered priority individuals for conservation and can inform conservation programs for Anacardium spp.
\end{abstract}

Keywords: Anacardium. Conservation. Genetic resources. Population structure.

\section{Introduction}

The Brazilian Cerrado is considered a hotspot of biodiversity and presents a richness of fruit species with great potential for economic utilization (Myers et al. 2000). The native fruit species of this biome are traditionally used by the local population and provide an alternative source of income (Campos et al. 2015). 
Among the commonly used fruit species in the Brazilian Cerrado, cajui (Anacardium spp.) has particular significance. The fruit and pseudofruit are rich in nutrients, being consumed in different ways by the local population in areas of natural occurrence of these species (Maia et al. 2019). The term 'cajui' (small cashew fruit) is used to describe species of the genus Anacardium L. that produce small nuts (cashews) and peduncles (Borges et al. 2018). The genus Anacardium, family Anacardiaceae, is native to Neotropical regions and presents two centers of diversity: one in the Central Amazon and the other in the Brazilian Cerrado (Mitchell and Mori 1987). Both the nut (fruit) and the peduncle (pseudofruit) can be consumed in natura or in the form of juices and sweets (Campos et al. 2015; Porto et al. 2016). In addition, the peduncles can be used to produce granola, which is highly nutritious, and liqueurs (Oliveira et al. 2011; Souza and Silva 2015). The peduncle presents high contents of vitamin $C$ and antioxidant compounds indicated for the prevention or therapy of pathologies in cells under oxidative stress (Barbosa-Filho et al. 2014).

However, although to its economic potential, the lack of conservation strategies may lead to this genus is susceptible to genetic erosion (Cota et al. 2017). The loss of genetic variability may compromise the long-term viability of populations and the potential of species to adapt to environmental changes (Fajardo et al. 2017). Thus, it is necessary to increase our knowledge of this genus and develop strategies for its conservation.

Native populations of cajui are found in Sete Cidades National Park (PNSC) in northeastern Brazil. Several studies regarding PNSC vegetation have been conducted, but knowledge of the diversity and genetic structure of the park's native fruit species is scarce. Nonetheless, information regarding genetic diversity is key for developing strategies for conserving genetic resources. Genetic variation can be evaluated by using molecular markers, such as inter-simple sequence repeats (ISSRs). ISSR analysis is a simple and efficient technique that does not require previous knowledge of the genome of the taxon under study (Duarte et al. 2018; Tian et al. 2018; Mariano et al. 2019).

Thus, the present study aimed to assess the amount of the genetic differentiation among populations of cajui in the PNSC by ISSR. The genetic information from our study will support conservation programs of Anacardium spp.

\section{Material and Methods}

\section{Study sites and sampling}

A total of 56 individuals of Anacardium spp. were collected from Cerrado areas in PNSC, which is located between the cities of Brasileira and Piracuruca (PI-Brazil). Although we could not identify the plant material to a species-level, all samples belong to the genus Anacardium and correspond to cajui trees due to the small sizes of the chestnut and peduncle. The sampling area represented three natural populations: Descoberta (12 individuals), Lagoa Seca (24 individuals) and 5a Cidade (20 individuals) (Table 1, Figure 1). Our sampling strategy aimed to achieve samples representative of the various phytophysiognomies in the Brazilian Cerrado from various areas within PNSC (Table 1). 


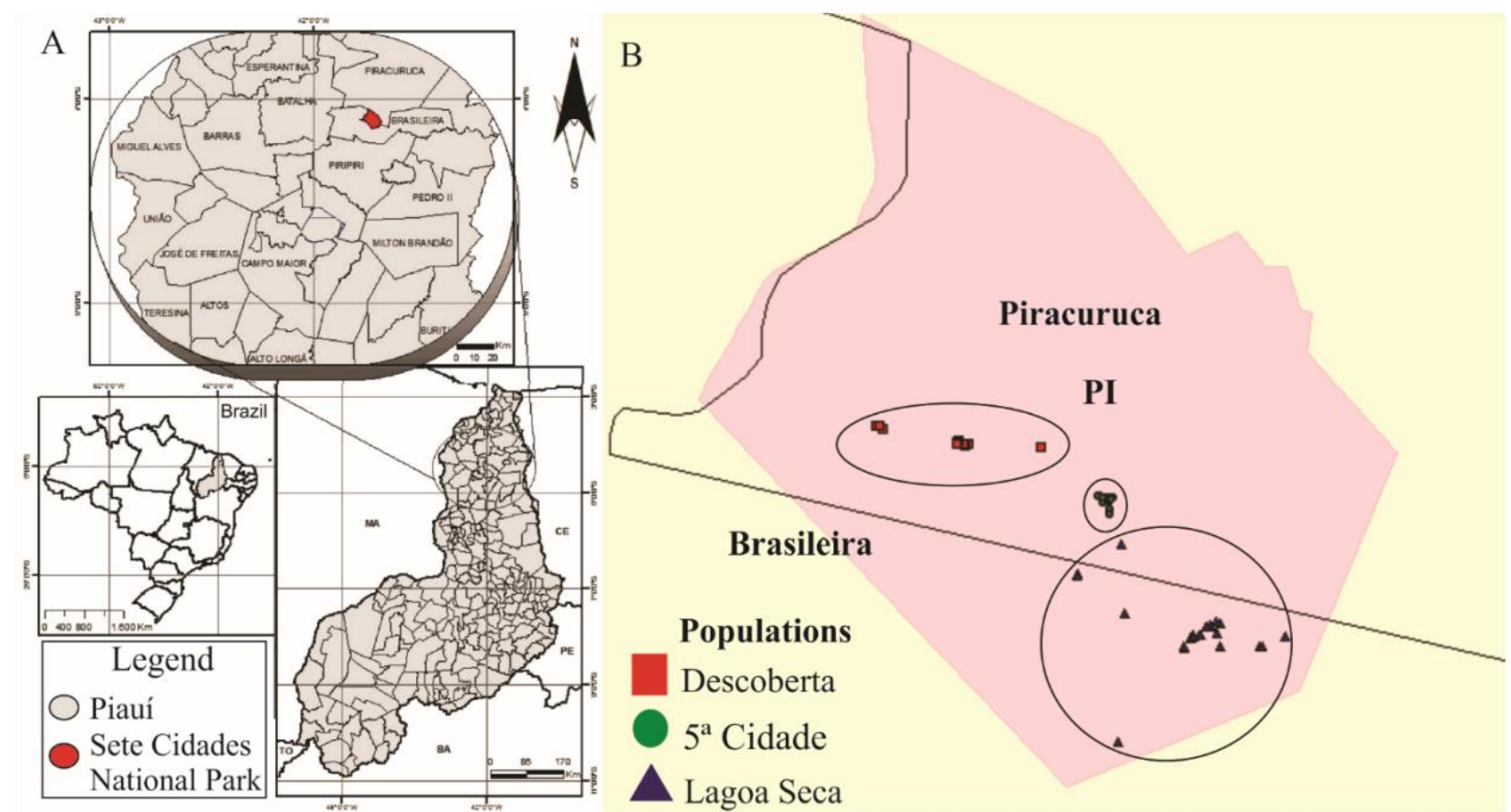

Figure 1. Area of study, Sete Cidades National Park, Piracuruca and Brasileira, Piauí, northeastern Brazil. A - map of Brazil with Sete Cidades National Park highlighted in red (adapted from Costa et al. 2016); B sampled populations of cajui (Anacardium spp.): Descoberta, 5a Cidade and Lagoa Seca (map was created using the speciesMapper tool available from http://splink.cria.org.br/mapper?criaLANG=pt).

Table 1. Cajui populations collected in Sete Cidades National Park, Piracuruca and Brasileira (PI), Brazil.

\begin{tabular}{ccccc}
\hline Population & $\begin{array}{c}\text { Number of } \\
\text { individuals }\end{array}$ & Individual labels & $\begin{array}{c}\text { Phytophysiognomy } \\
\text { of the Cerrado }\end{array}$ & $\begin{array}{c}\text { Mean distance between } \\
\text { populations }(\mathrm{km})\end{array}$ \\
\hline Descoberta (A) & 12 & C1-C12 & $\begin{array}{c}\text { Typical and } \\
\text { Rupestre Cerrado }\end{array}$ & $4.6(\mathrm{~A}-\mathrm{B})$ \\
Lagoa Seca (B) & 24 & $\begin{array}{c}\text { C13-C30, C32, C34, } \\
\text { C36, C38-C40 } \\
\text { C41-C60 }\end{array}$ & Typical Cerrado & $2.5(\mathrm{~B}-\mathrm{C})$ \\
5a Cidade (C) & 20 & Cerradão & $2.2(\mathrm{~A}-\mathrm{C})$ \\
\hline
\end{tabular}

The characteristics of each phytophysiognomy are as follows: typical Cerrado, a herbaceous vegetation layer and a shrub-tree layer with a height of approximately $5 \mathrm{~m}$, and plants with irregular and twisted branches; Cerrado Rupestre, plants up to $2 \mathrm{~m}$ high in rocky environments; and Cerradão, forest vegetation with tall, straight trees with an average height of $7 \mathrm{~m}$ (Castro et al. 2010). The mean distances between populations are shown in Table 1. The greatest geographic distance between individuals within PNSC was $6.8 \mathrm{~km}$, between individuals 03 (population Descoberta) and 25 (population Lagoa Seca) (Figure 1). Individuals were georeferenced by GPS. In addition, two A. occidentale accessions (Caju I and Caju II) from Pacajus (Ceará - Brasil) were used as an outgroup.

Samples of young, healthy leaves were collected, placed in a saturated solution of cetyltrimethylammonium bromide and sodium chloride (CTAB-NaCl) and stored at $-20^{\circ} \mathrm{C}$ until DNA extraction.

\section{DNA extraction and amplification of ISSRs}

Total DNA from $100 \mathrm{mg}$ of each plant sample was extracted following Doyle and Doyle (1987) with the following modifications: The volume of extraction buffer for lysis was increased to 1000L, and the chloroform:isoamyl alcohol (24:1) step was performed twice to increase DNA quality. The DNA was subjected to electrophoresis on $0.8 \%$ agarose gels prepared in $0.5 \mathrm{X}$ tris-borate-EDTA (TBE) buffer, stained with GelRed $^{\mathrm{TM}}$ dye and photographed under ultraviolet light. DNA quantification was performed by comparison with $\lambda$ DNA standards (100 ng). The purity of the samples was examined on a NanoDrop 2000 
spectrophotometer (Thermo Scientific). The DNA from each sample was diluted to $7 \mathrm{ng} / \mu \mathrm{L}$ and stored at $20^{\circ} \mathrm{C}$ for subsequent PCR.

The DNA amplification reactions were performed in a Veriti 96-well Thermal Cycler (Applied Biosystems ${ }^{\circledR}$, USA) with an initial denaturation for $1.5 \mathrm{~min}$ at $94^{\circ} \mathrm{C} ; 40$ cycles of denaturation for $40 \mathrm{sec}$ at $94^{\circ} \mathrm{C}$, annealing for $45 \mathrm{sec}$ at the optimized temperatures for the individual primers, and extension for $2 \mathrm{~min}$ at $72^{\circ} \mathrm{C}$; and a final extension of $7 \mathrm{~min}$ at $72^{\circ} \mathrm{C}$. Each reaction mixture contained $1 \mu \mathrm{L}$ DNA $(7 \mathrm{ng} / \mu \mathrm{L}), 0.8 \mathrm{mM}$ dNTPs (dATP, dCTP, dGTP, and dTTP), $1 \cup$ Taq DNA polymerase (Invitrogen), $0.8 \mu \mathrm{M}$ primer, $2.0 \mathrm{mM} \mathrm{MgCl}$, 1X Taq buffer [20 mM Tris-HCl, pH 8.0; 0.1 mM EDTA; $1 \mathrm{mM} \mathrm{DTT;} \mathrm{50 \%} \mathrm{(v/v)} \mathrm{glycerol]} \mathrm{and} \mathrm{ultrapure} \mathrm{H}_{2} \mathrm{O}$ in a $10 \mu \mathrm{L}$ final volume. The amplification products were subjected to electrophoresis on $1.5 \%$ agarose gel stained with GelRed ${ }^{\mathrm{TM}}$ dye in $0.5 \mathrm{X}$ TBE buffer for four hours at $100 \mathrm{~V}$. The gel was visualized under a UV transilluminator and photographed. The sizes of the amplicons were estimated by comparison with $1 \mathrm{~kb}$ DNA ladder (Invitrogen).

Twenty primers developed by the University of British Columbia (UBC), Vancouver, Canada, were tested to screen for the best amplification profiles. Among them, eleven primers yielding greater resolution of amplicons and higher levels of polymorphism were selected for further study (Table 2).

Table 2. ISSR primers (UBC) used in the molecular characterization of 58 individuals of Anacardium spp.

\begin{tabular}{ccccc}
\hline Primer & $\mathrm{Tm}\left(\mathrm{C}^{\circ}\right)$ & $\mathrm{Ta}\left({ }^{\circ} \mathrm{C}\right)$ & Sequence $\left(5^{\prime}-3^{\prime}\right)$ & $\mathrm{GC}(\%)$ \\
\hline UBC808 & 48.8 & 54.0 & AGA GAG AGA GAG AGA GC & 52.94 \\
UBC818 & 51.0 & 49.0 & CAC ACA CAC ACA CAC AG & 52.94 \\
UBC826 & 57.2 & 56.0 & ACA CAC ACA CAC ACA CC & 52.94 \\
UBC834 & 49.2 & 54.0 & AGA GAG AGA GAG AGA GYT & 50.00 \\
UBC836 & 48.9 & 52.0 & AGA GAG AGA GAG AGA GYA & 50.00 \\
UBC840 & 47.4 & 52.0 & GAG AGA GAG AGA GAG AYT & 50.00 \\
UBC841 & 48.5 & 51.0 & GAG AGA GAG AGA GAG AYC & 55.55 \\
UBC842 & 48.8 & 49.0 & GAG AGA GAG AGA GAG AYG & 55.55 \\
UBC845 & 48.1 & 50.0 & CTC TCT CTC TCT CTC TRG & 55.55 \\
UBC857 & 54.3 & 55.0 & ACA CAC ACA CAC ACA CYG & 55.55 \\
UBC864 & 43.6 & 50.0 & ATG ATG ATG ATG ATG & 33.33 \\
\hline
\end{tabular}

Tm, melting temperature; $\mathrm{Ta}$, annealing temperature; $\mathrm{Y}=\mathrm{C}$ or $\mathrm{T} ; \mathrm{R}=\mathrm{A}$ or $\mathrm{G}$.

\section{Statistical analysis: population genetic diversity}

The amplification profiles were scored manually for the presence (as 1) or absence (as 0) of bands, and a binary matrix was created. The Sorensen-Dice coefficient was calculated using PAST v. 3.08 software (Hammer et al. 2001) to evaluate genetic similarity between populations. POPGENE v. 1.32 software (Yeh et al. 1999) was employed to determine genetic diversity within and among the populations, measured as the percentage of polymorphic loci (P), Nei's genetic diversity (h) (Nei 1987), the Shannon index (I) (Lewontin 1972), the coefficient of genetic differentiation (GST) and indirect gene flow (Nm).

\section{Statistical analysis: genetic structure}

Analysis of molecular variance (AMOVA), performed with 10,000 permutations to test for significance, and genetic differentiation (DST) analysis were conducted using ARLEQUIN v. 3.5.1.2 software (Excoffier and Lischer 2010) to determine the amount of genetic variability within and among the populations. Bayesian analysis using Structure v. 2.3.4 software (Pritchard et al. 2000) was conducted to infer the number of genetic groups $(K)$ that best represented each sampled population. The $K$ values evaluated ranged from $K=1$ to $K=7$, and an admixture ancestry model using the correlated allele frequency option and the default parameters was used (Evanno et al. 2005). Ten independent runs were performed for each K, using 1,000,000 Monte Carlo Markov Chain (MCMC) simulations and a burn-in of 500,000. The number of genetic groups, $K$, was identified according to the $\Delta K$ method (Evanno et al. 2005) as implemented in the Structure Harvester program (Earl and Vonholdt 2012). 


\section{Results}

\section{ISSR markers}

A total of 11 primers were selected for ISSR analysis, which generated 112 fragments, of which 93 were polymorphic (83.04\%). The highest number of bands was obtained with primer UBC 834 (14 fragments), and the lowest number was obtained with primers UBC 840 and UBC 845 ( 7 fragments each), with a mean of $\sim 10$ fragments per primer. Amplicon size ranged from 150 to $2200 \mathrm{bp}$ (Table 3). The amplification profile of primer UBC 834 is shown in Figure 2.

Table 3. Primers used, band sizes, and number of amplified and polymorphic loci from 11 ISSR primers.

\begin{tabular}{ccccc}
\hline \multirow{2}{*}{ Primer } & \multirow{2}{*}{ Band size (bp) } & Total & Loci & \multirow{2}{*}{ Polymorphism (\%) } \\
\cline { 3 - 4 } & & 11 & 10 & 90.9 \\
UBC808 & $300-1500$ & 8 & 8 & 100.0 \\
UBC818 & $250-1550$ & 12 & 11 & 91.7 \\
UBC826 & $400-2000$ & 14 & 11 & 78.6 \\
UBC834 & $150-2000$ & 12 & 9 & 75.0 \\
UBC836 & $200-1800$ & 7 & 7 & 100.0 \\
UBC840 & $300-1500$ & 10 & 8 & 80.0 \\
UBC841 & $500-2200$ & 13 & 10 & 76.9 \\
UBC842 & $200-1650$ & 7 & 6 & 85.7 \\
UBC845 & $500-1850$ & 8 & 8 & 100.0 \\
UBC857 & $400-1300$ & 10 & 5 & 50.0 \\
UBC864 & $250-1100$ & 112 & 93 & 83.04 \\
Total & $150-2200$ & & & \\
\hline
\end{tabular}

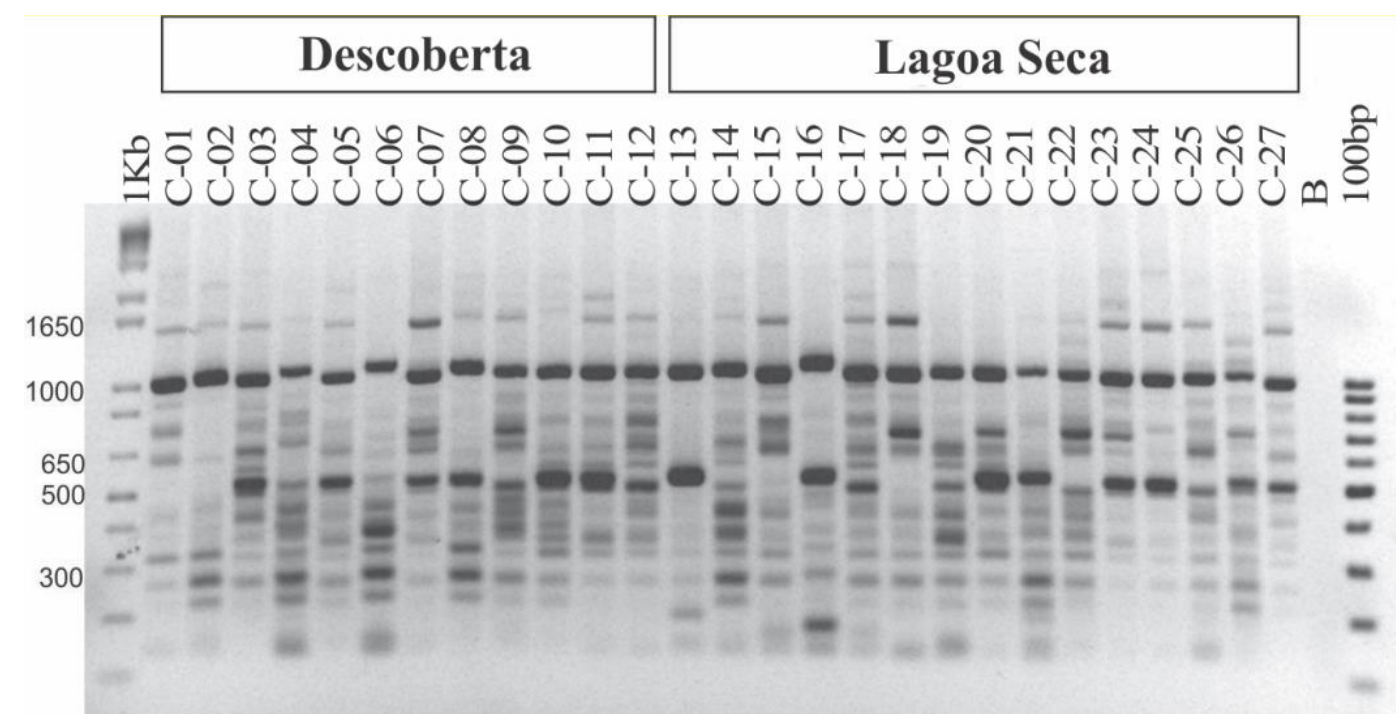

Figure 2. Gel profiles obtained from the DNA amplification of 27 cajui individuals from Sete Cidades National Park, located in Descoberta (12) and Lagoa Seca (15), with primer 834 (UBC). B, blank (negative control).

\section{Genetic similarity}

Genetic similarity between individuals of Anacardium spp. ranged from 0.60, observed between individuals C-23 (population Lagoa Seca) and Caju-II (BAG), to 0.94, observed between individuals C-26 and C-27; the latter were both collected in PNSC (population Lagoa Seca). The mean similarity was 0.81 . In general, the lowest similarity values were found between PNSC and outgroup individuals. The most divergent individuals compared to the outgroup were C-13, C-16, C-22, C-23 and C-44, with average similarity values of $0.63,0.64,0.65,0.61$ and 0.63 , respectively. The lowest similarity value, 0.67 , was found between C-22 and C-26, both belonging to population Lagoa Seca from PNSC. 


\section{Population genetic diversity}

Among the populations, population Lagoa Seca showed the highest percentage of polymorphism (78.57\%), whereas population Descoberta presented the lowest (61.61\%). Nei's genetic diversity $(\mathrm{h})$ ranged from 0.22 to 0.27 , with a total of 0.26 . The Shannon index (I) ranged from 0.33 to 0.40 , with a total of 0.39 . According to the differentiation index $\left(\mathrm{G}_{\mathrm{ST}}\right)$, only $6.94 \%$ of the genetic diversity occurred among the populations. The estimate of average gene flow $(\mathrm{Nm})$ was 6.70 , indicating a high level of gene flow among the populations (Table 4).

Table 4. Estimates of genetic diversity, number of migrants and genetic differentiation of the three populations of Anacardium spp.

\begin{tabular}{ccccccc}
\hline Population & PL & PPL (\%) & h & I & Nm & GsT \\
\hline Descoberta & 69 & 61.61 & 0.22 & 0.33 & & \\
Lagoa Seca & 88 & 78.57 & 0.27 & 0.40 & \\
5a Cidade & 81 & 72.32 & 0.24 & 0.36 & & \\
Total & 93 & 83.04 & 0.26 & 0.40 &
\end{tabular}

Subpopulations

6.70

0.07

PL, polymorphic loci; PPL, percentage of polymorphic loci; $h$, Nei's diversity index, l, the Shannon diversity index; Nm, number of migrants; $G_{\text {ST, }}$ index of genetic differentiation between populations.

\section{Genetic structure and differentiation}

The AMOVA results showed that a higher proportion of genetic variation was explained by differences within populations (96.17\%). In addition, low genetic differentiation was observed between the populations $\left(\Phi_{S T}=0.04\right)$ (Table 5).

Table 5. Molecular analysis of variance (AMOVA) of three populations of Anacardium spp.

\begin{tabular}{cccccc}
\hline $\begin{array}{c}\text { Source of } \\
\text { variation }\end{array}$ & DF & Sum of squares & $\begin{array}{c}\text { Component of } \\
\text { variance }\end{array}$ & $\begin{array}{c}\text { Percentage of } \\
\text { variance }\end{array}$ & $\begin{array}{c}\text { Fixing index } \\
\text { (ФST) }\end{array}$ \\
\hline $\begin{array}{c}\text { Between } \\
\text { populations } \\
\begin{array}{c}\text { Within } \\
\text { populations }\end{array}\end{array}$ & 2 & 50.45 & 0.58 & 3.83 & 0.04 \\
\hline
\end{tabular}

DF, degrees of freedom; P-value, probability of significance.

The Bayesian analysis performed using the Structure software indicated that the clusters were not strongly correlated with geographical locations, with individuals from the same collection point being very likely to belong to more than one genetic group. The $\Delta \mathrm{K}$ statistic indicated $\mathrm{K}=4$ as the probable number of genetic groups of Anacardium spp. (Figure 3).

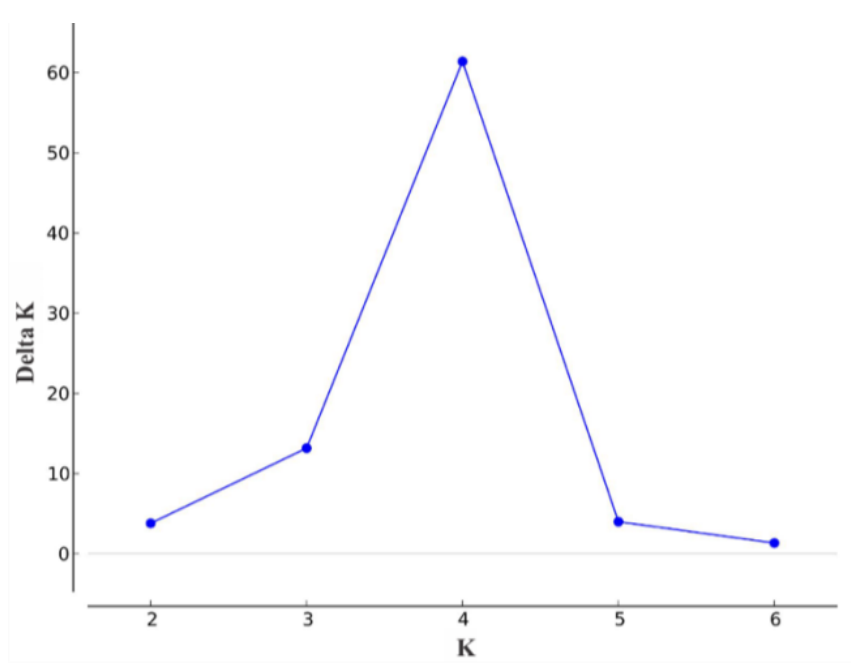

Figure 2. Values of $\Delta K$ estimated for populations of Anacardium spp., as proposed by Evanno et al. (2005). 
All individuals were differentiated into four different genetic groups to varying degrees (Figure 4). The genetic group that appeared in the greatest proportion is indicated in Figure 4 in blue (42\%) for the Descoberta population, yellow (31\%) for the Lagoa Seca population and green (38\%) for the 5a Cidade population. However, no predominance was observed, with no group having a proportion greater than $50 \%$. This result indicated a considerable mixture of genotypes among these genetic groups. Only the outgroup sample presented a genetic group with a predominance of greater than $80 \%$, represented by red in the figure, highlighting the divergence of the outgroup individuals from the others (Figure 4). The results agreed with the genetic similarity analysis of the populations.

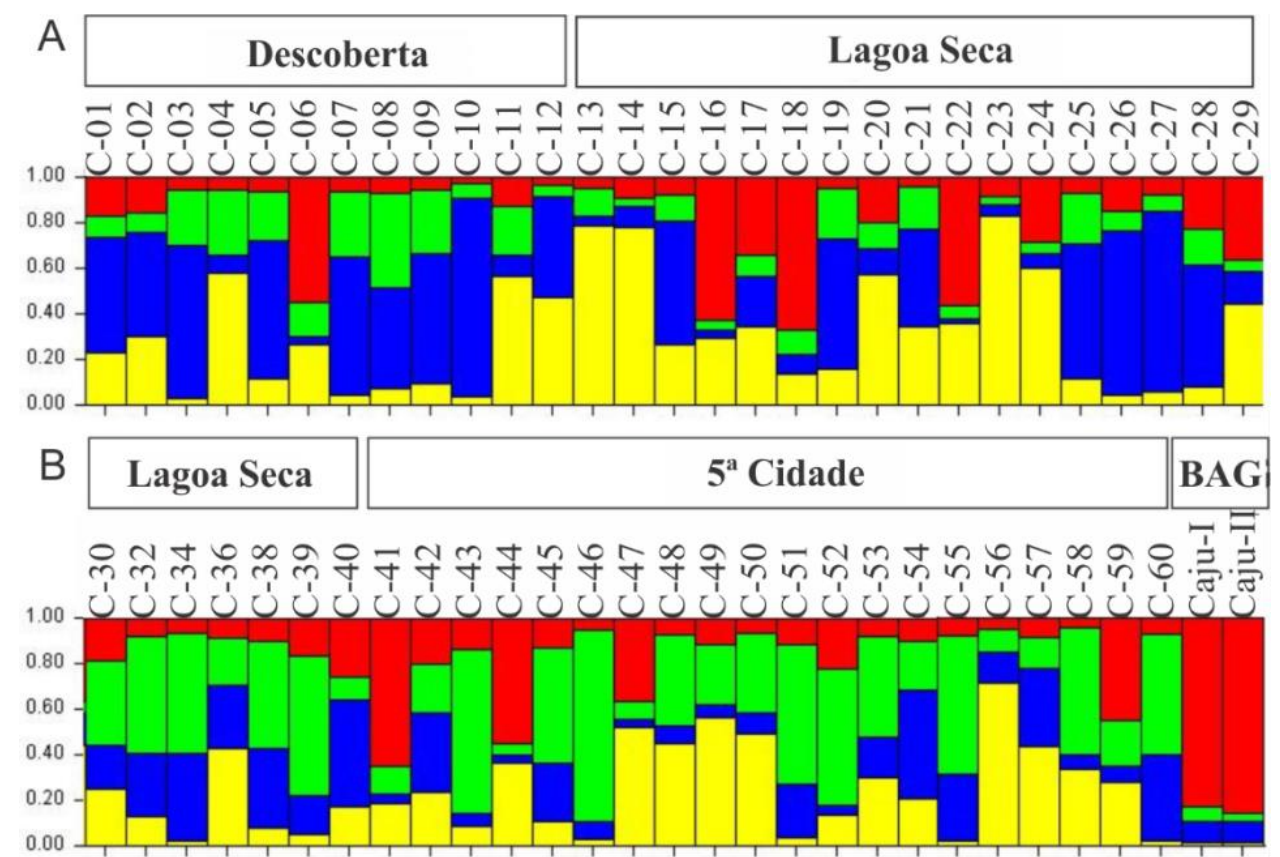

Figure 3. Graphical representation of the Structure analysis results, showing the individuals of Anacardium spp. distributed into four genetic groups. A - strucuture genetic of Descoberta and Lagoa Seca populations; B - structure genetic of Lagoa Seca and 5a Cidade populations and two accessions from Pacajus (Caju-I and Caju-II).

\section{Discussion}

In this study, genetic polymorphism in the populations was evaluated through the use of molecular markers that have the advantage of not being influenced by environmental factors (Laakili et al. 2018). Dominant markers, such as ISSRs, allow rapid, simple, and reproducible analysis and exhibit sufficient polymorphism to assess genetic diversity or identify closely related cultivars in many species, including fruit trees (Santos et al. 2015; Paschoa et al. 2018). Therefore, we used an ISSR approach to evaluate the diversity and genetic structure of cajui from three natural populations in PNSC and two accessions from Pacajus (Caju I and Caju-II).

The percentage of polymorphic loci indicates the effectiveness of molecular markers for estimating genetic variability in populations (Grativol et al. 2011). From the 11 ISSR primers employed, 112 loci were obtained, of which $83.04 \%$ were polymorphic. Hence, these ISSR markers were found to be effective for characterizing and discriminating genetic diversity in the individuals of Anacardium spp.

The most similar individuals, C-26 and C-27 (94.0\%), and the most divergent ones within PNSC, C-22 and C-26 (32.5\%), belong to the same collection population (population Lagoa Seca). Additionally, the most geographically distant individuals (C-03 and C-25) were very similar (87.3\%). Thus, the distribution of genetic diversity was not significantly influenced by geographic distance. The Sorensen-Dice coefficient among the individuals ranged from a maximum of 0.94 (between individuals C-26 and C-27) to a minimum of 0.60 (between C-23 and Caju-II). Considering only the individuals from PNSC, the range of diversity was low (6$32.5 \%)$, which indicated low to moderate genetic variability between individuals. This low variability may be related to the small number of founding genotypes of these populations and/or genetic drift due to the occurrence of fires in the park region (Souza and Pereira 2019). 
The finding of moderate estimated genetic variability was supported by the diversity indexes. In general, Nei's diversity index (h) ranges from 0 to 0.5 for dominant markers. In this study, Nei's diversity index was estimated at 0.26 , and the Shannon index (I) was 0.40 . The largest population examined, Lagoa Seca (24 individuals), presented the highest values of both Nei's diversity index $(h=0.27)$ and the Shannon index $(I=0.40)$. In contrast, the Descoberta population, with 12 individuals, presented the lowest genetic diversity $(h=0.22, I=0.33)$, which was possibly influenced by the small sample size. Therefore, the three populations presented moderate genetic variability, possibly due to the small sample sizes in this study, the genetic constitution of the founding genotypes, and/or genetic drift.

Analysis of the genetic diversity of natural cashew populations (Anacardium humile) in GO-Brazil, by RAPD, revealed higher Nei (0.3842) and Shannon (0.5662) diversity rates than our work, indicating greater genetic diversity of cajui in the cerrado of the Brazil (Santos et al. 2019). This reinforces the need for conservation strategies in the PNSC's cashew species.

AMOVA indicated that most genetic variability lies within the populations (96.17\%) and that there is low differentiation among them. This result is consistent with the reproductive biology of members of the genus Anacardium, which are predominantly allogamic (Aliyu 2008; Chhajer et al. 2018). In addition, although the inflorescences of these species comprise male and hermaphrodite flowers, self-fertilization is mechanically limited, which limits genetic differentiation among populations (Eradasappa and Mohana 2016).

The GST (0.07) and index of fixation (0.04) obtained by AMOVA were similar and indicated low genetic differentiation among the populations. This finding suggested a high level of gene flow, which was supported by the high number of migrants $(\mathrm{Nm}=6.70)$ per generation. Gene flow between populations may directly affect the distribution of genetic variation, since it represents the introduction of new allelic variants that can reduce genetic differentiation among populations (Hamrick 2012). One or more migrants per generation are considered sufficient to avoid population substructure (Sheidai et al. 2016). Thus, the high value of $\mathrm{Nm}$ (6.7028) explains the low differentiation found among the cajui populations of PNSC.

The Bayesian analysis obtained with Structure software and the similarity values together indicate high admixture of genotypes in the PNSC population, demonstrating that the individuals sampled at the different sites within PNSC do not represent structured subpopulations. The observed population admixture may be attributed to factors such as high gene flow, favored by the morphological and reproductive characteristics of the flowers of Anacardium spp., pollinators and small-animal seed dispersers. However, there is differentiation between the cajui species and the two individuals comprising the outgroup ( $A$. occidentale).

An important factor that promotes gene flow among Anacardium populations is the floral biology of the plant. The hermaphrodite flower has short stamens that do not reach the single long pistil, which makes self-fertilization difficult (Eradasappa and Mohana 2016). In addition, the higher production of male flowers than of hermaphrodite flowers, which has been detected for $A$. occidentale commercial species, early dwarf cashew and Anacardium giganteum, promotes reproduction by allogamy (Sousa et al. 2007; Takehana et al. 2013). The characteristics of Anacardium floral morphology, such as nectar quality, pollen grain traits, aroma, flower color, structure and size of the flowers and quantity of flowers produced, contribute significantly to the attraction of bees as pollinators (Takehana et al. 2013; Eradasappa and Mohana 2016). Therefore, floral biology directly affects the pollination mode of the plant, favoring cross-pollination in Anacardium. Gene flow is also facilitated by the small distances between populations. Bees, especially Apis mellifera, are the main dispersing agents of Anacardium pollen and can travel long distances in search of floral foods (Hagle et al. 2011). Since the greatest distance between the cajui individuals within PNSC did not exceed $6.8 \mathrm{~km}$, gene flow was likely promoted by pollen transport by bees in the region.

Gene flow through seed dispersion is also possible; the fruit is associated with a fleshy and succulent peduncle that attracts small animals, mainly frugivorous bats, which can disperse the fruit over long distances (Galindo-González 1998). The peduncle is also a food source for parrots and parakeets, which are frequent visitors to cajui plants in PNSC and possibly act as seed-dispersing agents. Thus, the high dispersal potential of Anacardium species via pollinators and seed dispersers, the high pollen viability in the genus, which exceeds $90 \%$ in two cajui species (Anacardium microcarpum and Anacardium pumilum), and the high germination percentages, culminate in high gene flow (Eradasappa et al. 2014; Moreira et al. 2016). 
In addition to having economic, medicinal, and ecological potential, the populations of Anacardium evaluated in the present study were under adverse environmental conditions, such as drought and poor soil. Because they can survive in such conditions, these individuals may contain genes responsibles for plant defense under abiotic stress. Fires of criminal origin are common within PNSC (Souza and Pereira 2019), and alleles with potential for exploitation by breeding programs may be lost; thus, ex situ conservation of these materials is necessary. For the ex situ conservation of these materials we suggest the most divergent cajui individuals analyzed: C-03, C-05, C-22, C-26, C-34 and C-39.

\section{Conclusions}

The set of ISSR markers tested in this study was effective for characterizing the Anacardium spp. individuals and represents a valuable tool for genetic breeding projects. The genetic diversity and population structure generated can allow the identification of high-priority genotypes for conservation.

Authors' Contributions: GOMES, M.F.C: conception and design, acquisition of data, analysis and interpretation of data, drafting the article, critical review of important intellectual content; BORGES, A.N.C.: acquisition of data, analysis and interpretation of data, critical review of important intellectual content; BATISTA, G.S.S.: acquisition of data; LUZ, G.A.: acquisition of data, analysis and interpretation of data, critical review of important intellectual content; OLIVEIRA, M.E.A.: acquisition of data; LOPES, A.C.A.: critical review of important intellectual content; ARAÚJO, A.S.F.: critical review of important intellectual content; GOMES, R.L.F.: critical review of important intellectual content; BRITTO, F.B.: analysis and interpretation of data, drafting the article, critical review of important intellectual content; LIMA, P.S.C.: conception and design, analysis and interpretation of data, drafting the article, critical review of important intellectual content; VALENTE, S.E.S.: conception and design, analysis and interpretation of data, drafting the article, critical review of important intellectual content. All authors have read and approved the final version of the manuscript.

Conflicts of Interest: The authors declare no conflicts of interest.

Ethics Approval: Not applicable.

Acknowledgments: The authors would like to thank the funding for the realization of this study provided by the Brazilian agencies FAPEPI (Fundação de Amparo a Pesquisa do Estado do Piauí - Brasil), and CAPES (Coordenação de Aperfeiçoamento de Pessoal de Nível Superior - Brasil), Finance Code 001.

\section{References}

ALIYU, O. Compatibility and fruit-set in cashew (Anacardium occidentale L.). Euphytica. 2008, 160(1), 25-33. https://doi.org/10.1007/s10681$\underline{007-9517-0}$

BARBOSA-FILHO, V.M., et al. Phytochemical constituents, antioxidant activity, cytotoxicity and osmotic fragility effects of caju (Anacardium microcarpum). Industrial Crops and Products. 2014, 55(1), 280-288. https://doi.org/10.1016/j.indcrop.2014.02.021

BORGES, A.N.C., et al. Genetic diversity in a cajui (Anacardium spp.) germplasm bank as determined by ISSR markers. Genetics and Molecular Research. 2018, 17(4), 1-14. http://dx.doi.org/10.4238/gmr18212

CAMPOS, L.Z.O., et al. Do socioeconomic characteristics explain the knowledge and use of native food plants in semiarid environments in Northeastern Brazil? Journal of Arid Environments. 2015, 115(1), 53-61. https://doi.org/10.1016/j.jaridenv.2015.01.002

CASTRO A.A.J.F., ARZABE, C. and CASTRO, N.M.C.F. Biodiversidade e ecótonos da região setentrional do Piauí. 1st ed. Teresina: Editora da Universidade Federal do Piauí, 2010.

CHHAJER, S., et al. Genetic diversity studies in endangered desert teak [Tecomella undulata (Sm) Seem] using arbitrary (RAPD), semi-arbitrary (ISSR) and sequence based (nuclear rDNA) markers. Trees. 2018, 32(4), 1083-1101. https://doi.org/10.1007/s00468-018-1697-9

COSTA, M.F., et al. Caracterização e divergência genética de populações de Casearia grandiflora no Cerrado piauiense. Floresta e Ambiente. 2016, 23(3), 387-396. https://doi.org/10.1590/2179-8087.007115

COTA, L.G., MOREIRA, P.A. and BRANDÃO, M.M. Structure and genetic diversity of Anacardium humile (Anacardiaceae): a tropical shrub. Genetics and Molecular Research. 2017, 16(1), 1-13. http://dx.doi.org/10.4238/gmr16039778

DOYLE, J.J. and DOYLE, J.L. A rapid DNA isolation procedure for small quantities of fresh leaf tissue. Phytochemical Bulletin. 1987, 19(1), 11-15.

DUARTE, A.B., GOMES, W.S. and NIETSCHE, S. Genetic diversity between and within full-sib families of Jatropha using ISSR markers. Industrial Crops and Products. 2018, 124(1), 899-905. https://doi.org/10.1016/j.indcrop.2018.08.066

EARL, D.A. and VONHOLDT, B.M. STRUCTURE HARVESTER: a website and program for visualizing STRUCTURE output and implementing the Evanno method. Conservation Genetics Resources. 2012, 4(2), 359-361. https://doi.org/10.1007/s12686-011-9548-7

ERADASAPPA, E., MOHANA, G.S., THIMMAPPAIAH and SAROJ, P.L. Pollen fertility in cultivated and wild species of cashew. Journal Plant Crops. 2014, 42(2), 268-271. 
ERADASAPPA, E. and MOHANA, G.S. Role of pollination in improving productivity of cashew - A review. Agricultural Reviews. 2016, 37(1), 6165. https://doi.org/10.18805/ar.v37i1.9266

EVANNO, G., REGNAUT, S. and GOUDET, J. Detecting the number of clusters of individuals using the software STRUCTURE: a simulation study. Molecular Ecology. 2005, 14(8), 2611-2620. https://doi.org/10.1111/j.1365-294X.2005.02553.x

EXCOFFIER, L. and LISCHER, H.E. Arlequin suite ver 3.5: a new series of programs to perform population genetics analyses under Linux and Windows. Molecular Ecology Resources. 2010, 10(3), 564-567. https://doi.org/10.1111/j.1755-0998.2010.02847.x

FAJARDO, C.G., et al. Negligence in the Atlantic Forest, northern Brazil: A case study of an endangered orchid. Biodiversity and Conservation. 2017, 26(5), 1047-1063. https://doi.org/10.1007/s10531-016-1285-5

GALINDO-GONZÁLEZ, J. Dispersion de semillas por murcielagos: su importancia en la conservation y regeneracion Del Bosque Tropical. Acta Zoológica Mexicana. 1998, 73(1), 54-57. https://doi.org/10.21829/azm.1998.73731727

GRATIVOL, C., et al. High efficiency and reliability of inter-simple sequence repeats (ISSR) markers for evaluation of genetic diversity in Brazilian cultivated Jatropha curcas L. accessions. Molecular Biology Reports. 2011, 38(7), 4245-4256. https://doi.org/10.1007/s11033-010-0547-7

HAGLE, J.R., et al. Foraging range of honeybees, Apis mellifera, in alfalfa seed production fields. Journal Insect Science. 2011, 11(1), 1-12. https://doi.org/10.1673/031.011.14401

HAMMER, $\varnothing .$, HARPER, D.A.T. and RYAN, P.D. PAST: Paleontological Statistics software package for education and data analysis. Paleontologia Electronica. 2001, 4(1), 1-9.

HAMRICK, J.L. Gene movement in tropical tree populations - Tropical breeding systems: one and done? Heredity. 2012, 109(1), $330-331$. https://doi.org/10.1038/hdy.2012.47

LAAKILI, A., et al. Diversity and spatial genetic structure of natural Moroccan Quercus susber L. assessed by ISSR markers for conservation. Physiology and Molecular Biology of Plants. 2018, 24(4), 643-654. https://doi.org/10.1007/s12298-018-0538-z

LEWONTIN, R.C. 1972. The apportionment of human diversity. In: DOBZHANSKY, T., HECHT, M.K. and STEERE, W.C. (eds). Evolutionary Biology. New York: Springer, pp. 381-398. https://doi.org/10.1007/978-1-4684-9063-3 14

MAIA, M.C.C., et al. Principal component and biplot analysis in the agro-industrial characteristics of Anacardium spp. European Scientific Journal. 2019, 15(30), 21-31. https://doi.org/10.19044/esj.2019.v15n30p21

MARIANO, L.C., et al. Genetic variability in a Brazilian apple germplasm collection with low chilling requirements. PeerJ. $2019,6(1)$, e6265. https://doi.org/10.7717/peerj.6265

MITCHELL, J.D. and MORI, S.A. The cashew and its relatives (Anacardium: Anacardiaceae). 1th ed. USA: New York Botanical Garden, $1987,1-76$.

MOREIRA, F.J.C., SILVA, M.A.P. and MEDEIROS-FILHO, S. Germinação e crescimento inicial de cajuí (Anacardium microcarpum DUCKE) em função do tamanho da semente e do tempo de embebição. Caderno de Cultura e Ciências. 2016, 15(1), 19-28.

MYERS, N., et al. Biodiversity hotspots for conservation priorities. Nature. 2000, 403(6772), 853-858. https://doi.org/10.1038/35002501

NEI, M. Molecular Evolutionary Genetics. 1st ed. New York: Columbia University Press, 1987.

OLIVEIRA, S.A.G., et al. Nutritional quality and protein value of exotic almonds and nut from the Brazilian Savanna compared to peanut. Food Research International. 2011, 44(7), 2319-2325. https://doi.org/10.1016/i.foodres.2011.02.013

PASCHOA, R.P.D., et al. Genetic diversity of populations of the dioecious Myrsine coriacea (Primulaceae) in the Atlantic Forest. Acta Botanica Brasilica. 2018, 32(3), 376-385. https://doi.org/10.1590/0102-33062017abb0355

PORTO, R.G.C.L., FETT, R. and AREAS, J.A.G. Bioactive compounds, antioxidant activity and minerals of Caju (Anacardium humile St. Hill) during the ripening. African Journal of Agricultural Research. 2016, 11(48), 4924-4930. https://doi.org/10.5897/AJAR2016.11455

PRITCHARD, J.K., STEPHENS, M. and DONNELLY, P. Inference of population structure using multilocus genotype data. Genetics. 2000, 155(2), 945-959.

SANTOS, S.C., CARVALHO, R. S. and DAVIDE, L.M.C. Genetic polymorphism among natural populations of Anacardium humile A. ST-HIL. Revista Brasileira de Fruticultura. 2019, 42(1), 1-8. http://dx.doi.org/10.1590/0100-29452020476

SANTOS, S.L.B., et al. Genetic variability in populations of Agave sisalana perrine detected by inter simple sequence repeats. Bioscience Journal. 2015, 31(6), 1624-1633. https://doi.org/10.14393/BJ-v31n6a2015-26420

SHEIDAI, M., et al. Genetic diversity in different populations of Persicaria minor (Polygonaceae), a medicinal plant. Nucleus. 2016, 59(2), 115121. https://doi.org/10.1007/s13237-016-0169-0

SOUSA, L.B., et al. Aspectos de biologia floral de cajueiros anão precoce e comum. Ciência Rural. 2007, 37(3), 882-885. https://doi.org/10.1590/S0103-84782007000300045

SOUZA, A.F.S. and PEREIRA, S.M.F. As queimadas no Parque Nacional de Sete Cidades: uma ameaça para a conservação da biodiversidade. Revista SOMMA. 2019, 5(1), 102-109.

SOUZA, P.L.C. and SILVA, M.R. Quality of granola prepared with dried caju-do-cerrado (Anacardium othonianum Rizz) and baru almonds (Dipteryx alata Vog). Journal of Food Science and Technology. 2015, 52(3), 1712-1717. https://doi.org/10.1007/s13197-013-1134-4 
TAKEHANA, C.L.I., et al. Biologia Floral e visitantes florais de Anacardium giganteum W. Hancock ex. Engl. (Anacardiaceae) no município de Bragança, Pará. Revista de Ciências Agrárias. 2013, 6(3), 202-211. http://dx.doi.org/10.4322/rca.2013.030

TIAN, H.Z., et al. Genetic diversity in the endangered terrestrial orchid Cypripedium japonicum in East Asia: Insights into population history and implications for conservation. Scientific Reports. 2018, 8(1), 1-13. https://doi.org/10.1038/s41598-018-24912-z

YEH, F., YANG, R. and BOYLE, T. Microsoft window-based freeware for population genetic analysis. 1a ed. Canada: University of Alberta, 1999.

Received: 25 April 2020 | Accepted: 14 December 2020 | Published: 29 December 2021

This is an Open Access article distributed under the terms of the Creative Commons Attribution License, which permits unrestricted use, distribution, and reproduction in any medium, provided the original work is properly cited. 